\title{
PENGARUH STRUKTUR ORGANISASI TERHADAP EFEKTIFITAS KERJA KARYAWAN PADA PT. INTI KARSA PERSADA (KALLA HOSPITALITY) MAKASSAR
}

\author{
Taufiq Wahyudi'1), Herman Sjahruddin²), Mustafa Ganii3) \\ taufiqwahyudi7@gmail.com
}

1) Mahasiswa Program Studi Manajemen pada Sekolah Tinggi Ilmu Ekonomi Bongaya Makassar

2,3) Dosen Program Studi Manajemen pada Sekolah Tinggi Ilmu Ekonomi Bongaya Makassar

\begin{abstract}
ABSTRAK
Penelitian ini bertujuan untuk menguji pengaruh struktur organisasi yang terdiri dari dimensi kompleksitas pekerjaan, formalisasi pekerjaan, dan sentralisasi pekerjaan terhadap efektifitas kerja karyawan pada PT. Inti Karsa Persada (Kalla Hospitality) Makassar. Pengumpulan data menggunakan data primer yang diperoleh dari kuesioner dengan menggunakan teknik proportionated random sampling. Poulasinya adalah seluruh karyawan pada PT. Inti Karsa Persada (Kalla Hospitality) Makassar sejumlah 86 karyawan, sedangkan sampel yang diambil berjumlah 62 responden. Hasil kuesioner tersebut telah diuji validitas dan reabilitasnya. Metode analisis data menggunakan teknik SEM (Sturctural equation modeling) dibantu dengan WarphPLS Ver.5.0. Hasil penelitian ini menunjukkan bahwa hipotesis kompleksitas pekerjaan diterima karena menunjukkan hasil uji hipotesis yang positif dan signifikan. Ini berarti bahwa berpengaruh kompleksitas pekerjan positif dan signifikan terhadap efektifitas kerja karyawan.kemudian hasil penelitian pada formalisasi pekerjaan menunjukkan bahwa hipotesis diterima karena menunjukkan hasil hipotesis yang positif dan signifikan . ini berarti bahwa berpengaruh formalisasi pekerjaan positif dan signifikan terhadap efektifitas kerja karyawan. Sedangkan hasil penelitian pada sentralisasi pekerjaan menunjukkan bahwa hipotesis diterima karena menunjukkan hasil hipotesis yang positif dan signifikan. Kondisi tersebut berarti bahwa pengaruh sentralisasi pekerjaan positif dan signifikan terhadap efektifitas kerja karyawan.
\end{abstract}

Kata kunci : Kompleksitas pekerjaan, Formalisasi pekerjaan, Sentralisasi pekerjaan, Efektifitas kerja.

ABSTRACT
This study aimed to examine the effect of organizational structure consisting of
dimensional complexity of the work, the formalization of employment, and the
centralization of the work on the effectiveness of employees at PT. Inti Karsa Persada
(Kalla Hospitality) Makassar. Collecting data using primary data obtained from
questionnaires using proportionate random sampling technique. 62 respondents
Population as much of 86 employees and 62 employees were used as samples in this

Author : Taufiq Wahyudi dkk. (September, 2017). 29 - 46

Halaman 29 


\section{JURNAL ORGANISASI DAN MANAJEMEN}

Issue 1 (September, 2017)

study. The results of the WarphPLS Ver.5.0 indicate that the hypothesis is accepted because it shows the complexity of the work is positive and significant effect on employee work effectiveness. This means that the effect on job retention complexity positive and significant impact on the employee work effectiveness. The research on work formalizing shows that the hypothesis is accepted because it is positive and significant results. This means that the effect of work formalization is positive and significantly effect on work effectiveness of the employee. While the centralization of work shows that the hypothesis is accepted because it is positive and significant. This means that the job centralization has a positive and significant effect of the employee work effectiveness.

Keywords: Complexity of the work, a formalization of employment, centralization of work, work effectiveness.

\section{Latar Belakang}

Hospitality Industry adalah industri terbesar di dunia yang aktivitas usahanya dilakukan dalam berbagai bentuk, salah satu dari bentuk aktivitas tersebut adalah usaha makanan dan minuman (food and bavarage), seiring dengan era globalisasi ini, hospitality industry berkembang begitu pesatnya, terlihat dari semakin banyaknya orang yang terlibat dalam industri ini. PT Inti Karsa Persada merupakan salah satu perusahaan yang bergerak dalam jasa usaha makanan dan minuman. Perusahaan dalam melaksanakan aktivitas bisnisnya sangat bergantung pada karyawannya.

Fakta lapangan menunjukkan adanya pelanggaran kerja yang dilakukan karyawan PT Inti Karsa Persada terhadap tugas dan tanggung jawab yang diberikan perusahaan, seperti yang ditunjukkan dengan adanya karyawan yang tidak melaksanakan tugas sesuai fungsinya, tidak mematuhi perintah atasan, masih adanya pekerjaan yang dibebankan kepada karyawan yang tidak dilaksanakan secara formal kemudian beban kerja yang diberikan karyawan terlalu kompleks,kondisi tersebut menyebabkan rendahnya efektifitas kerja karyawan.

Efektivitas kerja dalam defenisi konseptual adalah merupakan suatu ukuran tentang pencapaian suatu tugas dan tujuan, dalam defenisi operasional. Efektivitas kerja adalah skor tanggapan responden atas dasar keadaan dimana aktivitas jasmaniah dan rohaniah yang dilakukan oleh manusia dapat mencapai hasil akibat sesuai yang dikehendaki, dengan dimensi : kemampuan menyesuaikan diri (keluwesan), prestasi kerja, serta kepuasan kerja.

Berdasarkan pendapat diatas, efektifitas kerja karyawan merupakan ketepatan dalam pencapaian tujuan organisasi dengan memperdayakan sumber daya organisasi, mempelajari efektifitas organisasi ialah memadukan faktor-faktor organisasi, salah satunya struktur organisasi.

Struktur organisasi pada hakikatnya adalah suatu cara untuk menata unsurunsur dalam organisasi dengan sebaik-baiknya, demi mencapai berbagai tujuan yang telah ditetapkan (Kusdi, 2009:176). Oleh sebab itu, struktur organisasi menetapkan bagaimana tugas akan dibagi, siapa melapor kepada siapa, dan mekanisme koordinasi yang formal serta pola interaksi yang akan diikuti. Sebuah struktur organisasi mempunyai tiga komponen dimensi yaitu : kompleksitas, formalisasi, dan sentralisasi (Robbins,1994:6). Berdasarkan teorinya, kinerja individu merupakan interaksi antara kemampuan atau abality (A), motivasi atau motivation (M), yaitu Kinerja = $\mathrm{f}(\mathrm{A} \times \mathrm{M}$ x 0) . bahwa kinerja merupakan fungsi dan

Halaman 30

Author : Taufiq Wahyudi dkk. (September, 2017). 29 - 46 


\section{JURNAL ORGANISASI DAN MANAJEMEN}

Issue 1 (September, 2017)

kemampuan, motivasi dan kesempatan (Robbins, 1998; dalam Safariah,2013). Berdasarkan teori tersebut maka dapat dijelaskan bahwa variabel yang dianalisis dalam penelitian ini, yaitu kinerja merupakan penjabaran dari faktor kemampuan (abality) yaitu kemampuan karyawan untuk menyelesaikan pekerjaannya yang sifatnya kompleks. Berikutnya faktor motivasi merupakan penjabaran terhadap dorongan karyawan dalam bekerja yang dalam penelitian ini dicirikan dengan sentralisasi pekerjaan. Bahwa dengan sentralisasi pekerjaan atau pemusatan pekerjaan karyawan akan bekerja secara optimal yang disebabkan karena adanya dorongan dari dalam diri karyawan untuk mendapatkan penghargaan. Kemudian faktor yang terakhir Oppurtunity (peluang) merupakan penjabaran dari formalisasi pekerjaan, bahwa karyawan dalam melaksanan pekerjaan berkeinginan untuk memperoleh jabatan yang lebih tinggi (Promosi) dan untuk itu hanya dapat diperoleh dengan menunjukkan kemampuan karyawan untuk menyelesaikan pekerjaannya yang sifatnya formal (sesuai dengan deskripsi pekerjaannya).

Pengaruh antar variabel yang dibangun dalam penelitian skripsi ini,yaitu pengaruh struktur organisasi terhadap efektifitas kerja berpedoman pada teori efektifitas kerja, seperti pada studi GammahendraG dkk.,(2014);dan Budiasih (2012) bahwa struktur organisasi berpengaruh positif signifikan terhadap produktivitas kerja sebagai dari cerminan efektifitas kerja karyawan, hasil penelitian tersebut memperoleh bantahan dari peneliti lannya,bahwa pengaruh beban kerja sebagai cerminan dari struktur organisasi berpengaruh positif namun tidak signifikan terhadap kinerja karyawan yang ditunjukkan melalui efektifitas kerja karyawan (Astutik, 2016) .

Berdasarkan hasil penelitian terdahulu maka penelitian ini mengadopsi dan mengembankan penelitian Gammahendra $d k k$. (2014) yang mengukur struktur organisasi dengan menggunakan beberapa indikator yaitu; (1) kompleksitas pekerjaan , (2) formalisasi pekerjaan, dan (3) sentralisasi pekerjaan . kemudian untuk variabel efektivitas kerja diukur dengan indikator yaitu; (1) kemampuan menyesuaikan diri , (2) prestasi kerja ,dan (3) kepuasan kerja.

\section{Kajian Teoritis}

\section{Konsep Manajemen Sumber Daya Manusia}

Manajemen berasal dari kata "to manage" yang artinya mengatur. Pengaturan dilakukan melalui proses dan diatur berdasarkan urutan dari fungsifungsi manajemen tersebut. Manajemen adalah ilmu dan seni mengatur proses pemanfaatan sumber daya manusia dan sumber-sumber lainnya secara efektif dan efisien untuk mencapai suatu tujuan tertentu (Hasibuan, 2010:1, dalam Ramadhani, dkk., 2016).

Pada Ilmu manajemen terdapat cabang ilmu yang dinamakan manajemen sumber daya manusia. Manajemen sumber daya manusia meliputi segala kegiatan yang berkaitan dengan pengakuan pada pentingnya tenaga kerja pada organisasi sebagai sumber daya yang vital, yang memberikan sumbangan terhadap tujuan organisasi. Beberapa ahli mengemukakan pandangan tentang defenisi dari manajemen sumber daya manusia (MSDM) antara lain : Sumber Daya Manusia atau human recources mengandung dua pengertian. Pertama, usaha kerja atau jasa yang diberikan oleh seseorang dalam waktu tertentu untuk menghasilkan barang dan jasa. Pengertian kedua, SDM menyangkut manusia yang mampu bekerja untuk memberikan jasa atau usaha kerja tersebut, mampu bekerja berarti mampu melakukan kegiatan yang menghasilkan barang atau jasa untuk memenuhi 


\section{JURNAL ORGANISASI DAN MANAJEMEN}

Issue 1 (September, 2017)

kebutuhan atau masyarakat (Sumarsono, 2009:4, dalam Ramadhani, dkk., 2016). Pandangan lainnya menjelaskan bahwa manajemen sumber daya manusia adalah penarikan, seleksi, pengembangan, pemeliharaan, dan penggunaan sumber daya manusia untuk mencapai baik tujuan-tujuan individu maupun organisasi (Handoko, 2014:3, dalam Ramadhani, dkk., 2016). Kesamaan pandangan dalam menjelaskan manajemen SDM ditunjukkan (Bangun, 2012:6, dalam Ramadhani, dkk., 2016) berpendapat bahwa manajemen sumber daya manusia berkaitan dengan pengelolan manusia melalui aktivitas-aktivitas organisasi dan fungsi-fungsi operasionalnya.

Berdasarkan pengertian manajemen sumber daya manusia yang telah dikemukakan, maka dapat disimpulkan bahwa manajemen sumber daya manusia dapat didefinisikan sebagai suatu proses perencanaan, pengorganisasian, penyusunan staf, penggerakan dan pengawasan, terhadap pengadaan, pengembangan, pemberian kompensasi, pengintegrasian, pemeliharaan, dan pemisahaan tenaga kerja untuk mencapai suatu tujuan baik organisasi maupun individu.

Berdasarkan fungsinya, sumber daya manusia dapat dibedakan (Sutrisno, 2014:9, dalam Ramadhani, dkk., 2016) sebagai berikut:

1. Perencanaan merupakan kegiatan merencanakan tenaga kerja secara efektif serta efisien agar sesuai dengan kebutuhan perusahaan dalam membantu terwujudnya tujuan.

2. Pengorganisasian adalah kegiatan untuk mengatur karyawani dengan menetapkan pembagian kerja, hubungan kerja, delegasi wewenang, integrasi dan kordinasi, dalam bentuk bagan organisasi.

3. Pengarahan dan Pengadaan adalah kegiatan memberi petunjuk kepada pegawai, agar mau kerja sama dan bekerja efektif dan efisien dalam membantu tercapainya tujuan organisasi.

4. Pengendalian merupakan kegiatan mengendalikan pegawai agar mentaati peraturan organisasi dan bekerja sesuai dengan rencana. Bila terdapat penyimpangan diadakan tindakan perbaikan dan atau penyempurnaan.

Penjelasan lainnya menyangkut fungsi sumber daya manusia dikemukakan (Yunarsih, 2009, dalam Ramadhani, dkk., 2016) bahwa fungsi manajemen sumber daya manusia mecakup perencanaan, penempatan, pengevaluasian, pengembangan, dan mengatur hubungan yang efektif antar tenaga kerja. Mengacu pada fungsi manajemen sumber daya manusia yang telah dikemukakan, maka dapat disimpulkan bahwa fungsi manajemen sumber daya manusia adalah segala tindakan yang dilakukan guna menghasilkan sumber daya manusia yang berkualitas, produktif serta efektif bagi kelangsungan organisasi dan perusahaan.

\section{Konsep Struktur Organisasi}

Struktur organisasi pada hakikatnya adalah suatu cara untuk menata unsurunsur dalam organisasi dengan sebaik-baiknya, demi mencapai berbagai tujuan yang telah ditetapkan (Kusdi, 2009:176 dalam Gammahendra, dkk, 2014), Pengertian Struktur Organisasi menurut Benhard dalam (Malayu S.P Hasibuan, 2010:26 dalam Gina Maridana, 2011) adalah : "Struktur Organisasi adalah suatu gambar yang menggambarkan tipe organisasi, pendepartemenan organisasi, kedudukan dan jenis wewenang pejabat, bidang, dan hubungan kerja, garis perintah dan tanggung jawab, rentang kendali dan sistem pimpinan organisasi". Dari beberapa definisi tersebut dapat diketahui bahwa struktur organisasi menggambarkan kerangka dan susunan hubungan diantara fungsi, bagian atau

Halaman 32

Author : Taufiq Wahyudi dkk. (September, 2017). 29 - 46 


\section{JURNAL ORGANISASI DAN MANAJEMEN}

Issue 1 (September, 2017)

posisi, juga menunjukkan hierarki organisasi dan struktur sebagai wadah untuk menjalankan wewenang, tanggung jawab dan sistem pelaporan terhadap atasan dan pada akhirnya memberikan stabilitas dan kontinuitas yang memungkinkan organisasi tetap hidup walaupun orang datang dan pergi serta pengkoordinasian hubungan dengan lingkungan. Struktur organisasi dapat menghindari atau mengurangi kesimpangsiuran dalam pelaksanaan tugas.

Berdasarkan pengertian struktur organisasi yang telah dikemukakan, maka dapat disimpulkan bahwa struktur organisasi adalah suatu kompenen atau unit kerja dalam perusahaan yang membantu untuk mencapai tujuan perusahaan. Struktur organisasi menetapkan bagaimana tugas akan dibagi, siapa melapor kepada siapa, dan mekanisme koordinasi yang formal serta pola interaksi yang akan diikuti. Sebuah struktur organisasi mempunyai tiga komponen dimensi: kompleksitas, formalisasi, dan sentralisasi (Robbins, 1994:6 dalam Gina Maridana, 2011)Sehingga dimensi struktur organisasi yang lebih sering digunakan dalam riset dan praktik yang menggambarkan dimensi struktur, yaitu dimensi Kompleksitas, dimensi formalisasi, dan dimensi sentralisasi, untuk itu dapat dijelaskan sebagai berikut:

\section{Kompleksitas pekerjaan}

Kompleksitas merujuk pada tingkat differensiasi yang ada didalam sebuah organisasi. Differensiasi horizontal mempertimbangkan tingkat pemisahan horizontal diantara unit-unit. Differensiasi vertical merujuk pada kedalaman hierarki organisasi. Differensiasi spasial meliputi tingkat sejauh mana lokasi fasilitas dan para pegawai organisasi tersebar secara geografis. Differensiasi horizontal merujuk pada pengelompokan berdasarkan spesialisasi-spesialisasi yang ada dalam sebuah organisasi, baik spesialisasi fungsional maupun sosial. Pembagian departemen-departeman dalam organisasi dapat dilakukan berdasarkan jumlah orang, fungsi, produk atau jasa, klien, geografis, atau proses (Kusdi, 2009:169 dalam Gina Maridana, 2011)

Differensiasi vertical Merujuk pada kedalaman struktur. Diferensiasi meningkat, demikian pula kompleksitasnya, karena jumlah tingkatan hierarki didalam organisasi bertambah(Robbins, 1994 : 95 dalam Gammahendra, dkk, 2014).Organisasi dengan jumlah pegawai yang sama, tidak perlu mempunyai tingkat diferensiasi vertikal yang sama. Organisasi dapat berbentuk tinggi (tall), dengan banyak lapisan hierarki, atau mendatar (flat), dengan sedikit tingkatan.

Faktor yang menentukan adalah Rentang Kendali (Robbins, 1994 : 96 dalam Gammahendra, dkk, 2014). Organiasi dapat melakukan aktivitas yang sama dengan tingkat diferensiasi horizontal dan pengaturan hierarki yang sama diberbagai lokasi. Tetapi keberadaan barbagai lokasi tersebut meningkatkan kompleksitas (Robbins, 1994:98 dalam Gammahendra, dkk, 2014). Oleh karena itu, elemen ketiga dalam kompleksitas adalah diferensiasi spasial, yang merujuk pada tingkat sejauh mana lokasi kantor, pabrik dan personalia sebuah organisasi tersebar secara geografis. Pengukuran variabel kompleksitas dalam penelitian ini menggunakan pengukuran kompleksitas (Robbins, 1994:98 dalam Gammahendra, dkk, 2014) meliputi (1) Differensiasi horizontal,(2) Differensiasi vertical, dan (3) Diferensiasi spasial.

\section{Formalisasi pekerjaan}

Jika sebuah pekerjaan sangat diformalisasikan, maka pemegang pekerjaan itu hanya mempunyai sedikit kebebasan mengenai apa yang harus dikerjakan, 


\section{JURNAL ORGANISASI DAN MANAJEMEN}

Issue 1 (September, 2017)

bilamana mengerjakannya, dan bagaimana ia harus melakukannya"(Robbins, 1994:103 dalam Gammahendra, dkk, 2014).Para manajer mempunyai sejumlah teknik formalisasi yang diambil dari pendapat StepenP.Robbins dalam (Kusdi 2009:173 dalam Gammahendra, dkk, 2014), untuk dapat menstandarisasikan perilaku para pegawai. Pengukuran variabel formalisasi dalam penelitian ini menggunakan pengukuran formalisasi (Kusdi 2009:173 dalam Gammahendra, dkk, 2014) meliputi (1) proses seleksi, (2) persyaratan jabatan, (3) Peraturan, Prosedur, dan Kebijakan, (4) proses pelatihan, dan (5) ritual .

\section{Sentralisasi Pekerjaan}

Penjelasan terkait sentralisasi secara lebih khusus yaitu jenjang kepada siapa kekuasaan formal untuk membuat pilihan-pilihan secara leluasa dikonsentrasikan pada seorang individu, unit, atau tingkatan (biasanya berada tinggi pada organisasi), dengan demikian mengizinkan para pegawai (biasanya pada tingkat rendah dalam organisasi) untuk memberi masukan yang minimal ke dalam pekerjaan mereka (Robbins, 1994 :118 dalam Gammahendra, dkk, 2014). Sentralisasi dapat dijelaskan juga bahwa hal ini merujuk pada bentuk-bentuk keputusan yang mengandung kebebasan bagi seseorang. Istilah kuncinya adalah pilihan-pilihan bebas (discretionary choice), "jika dikatakan the director possesses certain discretionary funds, artinya direktur memiliki dana-dana tertentu yang boleh dikeluarkan atau digunakan sesukannya"(Kusdi, 2009:174 dalam Gammahendra, dkk, 2014). Kebebasan dalam memilih ini biasanya di konsentrasikan pada pucuk pimpinan atau level manajemen atas, dan untuk level manajemen bawah tidak mendapatkan peluang dalam memilih keputusan, kecuali pilihan-pilihan bebas ini dalam pelaksanaan tugas-tugasnya. Pengukuran variabel sentralisasi dalam penelitian ini menggunakan pengukuran sentralisasi Kusdi(2009), meliputi: Sentraliasi memperlihatkan kebebasan dalam pengambilan keputusan.

\section{Konsep Efektifitas kerja}

Efektivitas berasal dari kata effective, yang artinya berhasil atau ditaati. Keberhasilan organisasi dalam mencapai tujuan sangat bergantung pada kemampuan pegawai bekerja secara efektif yaitu bekerja sesuai dengan ketentuan dan mentaati setiap aturan yang dimiliki organisasi. (Echols dan Shadily,1997 dalam Machmud, 2013). (Barnard ,2005 dalam Machmud, 2013) menjelaskan Effectiveness is the degree to which operative goals have been attained dengan demikian efektivitas berkenaan dengan pencapaian tujuan kerja yang dimiliki oleh setiap pekerja, seseorang pegawai dinyatakan memiliki efektivitas kerja yang tinggi jika pegawai tersebut mampu mencapai tujuan yang dibebankan pada dirinya.

Berdasarkan pengertian efektifitas kerja yang telah dikemukakan, maka dapat disimpulkan bahwa efektifitas kerja adalah ukuran atau kualitas keberhasilan kerja yang dicapai pegawai. Seseorang pegawai dinyatakan bekerja efektif jika ia mampu mencapai tujuan dengan cara yang lebih baik dari standar yang telah ditetapkan. Efektivitas kerja pegawai dapat ditentukan dengan membandingkan antara waktu kerja yang telah ditetapkan dengan waktu yang dibutuhkan pegawai, dan juga dapat dibandingkan antara hasil atau kualitas yang dicapai dengan kualitas yang telah ditetapkan. Jika pelaksanaan kerja yang dilakukan pegawai lebih baik dari yang ditetapkan maka pegawai tersebut tergolong sebagai pegawai yang efektif. Pengukuran variabel efektifitas kerja dalam penelitian ini menggunakan 
Issue 1 (September, 2017)

pengukuran efektifitas kerja meliputi (1) standart operasional kerja, (2) ketepatan waktu,dan (3) kualitas pekerjaan.

\section{METODE PENELITIAN}

Penelitian ini termasuk penelitian metode deskriptif kuantitatif yang bertujuan untuk menjelaskan suatu fenomena empiris yang disertai data statistik dan pola hubungan antar variable. Pada penelitian ini variabel terikat Efektifitas kerja (Y) dipengaruhi oleh varibel bebas Struktur Organisasi (X) Penelitian ini menggunakan analisis SEM (Structural equation modelling) dibantu dengan WarphPLS Ver. 5.0). Teknik pengumpulan data dalam penelitian ini yaitu: observasi dan kuesioner. Pengukuran variabel dalam penelitian ini yang diukur menggunakan Skala Ordinal dengan menggunakan Skala Likert Poin 1 untuk jawaban sangat tidak setuju (STS), Poin 2 untuk jawaban tidak setuju (TS), Poin 3 untuk jawaban netral (N), Poin 4 untuk jawaban setuju (S), dan untuk poin 5 untuk jawaban sangat setuju (SS).

\section{Evaluasi Model Pengukuran (Outer Model) Model 1}

Evaluasi outer model dilakukan melalui 3 kriteria yaitu convergent validity, discriminant validity dan composite reliability. Berikut ini adalah hasil pengolahan data:

\section{a. Convergent Validity (Validitas Konvergen)}

Convergent validity dari model pengukuran dapat dilihat dari korelasi antara skor indikator dengan skor konstruknya (loading factor) dengan kriteria nilai loading factor dari setiap indikator lebih besar dari 0,70 dapat dikatakan valid. Selanjutnya untuk nilai p-value apabila $<0,05$ dianggap signifikan. Dalam buku (Machfud dan Dwi, 2013: 66 dalam Arista, 2015) dijelaskan bahwa dalam beberapa kasus, syarat loading di atas 0,70 sering tidak terpenuhi khususnya untuk kuesioner yang baru dikembangkan. Oleh karena itu, loading antara 0,40-0,70 harus tetap dipertimbangkan untuk dipertahankan. Selanjutnya dijelaskan pula bahwa, indikator dengan loading < 0,40 dihapus dari model. Penghapusan indikator dengan loading antara 0,40-0,70 dilakukan apabila indikator tersebut dapat meningkatkan AVE dan composite reliability diatas nilai batasannya. Nilai batasan untuk AVE 0,50 dan composite reliability adalah 0,50. Hasil pengolahan Convergent Validity dapat dilihat pada tabel berikut ini:

Tabel 1. Hasil output combined loadings and cross-loading

\begin{tabular}{|l|c|c|c|c|c|}
\hline MODEL 1 & Komplek & formali & sentral & E K & P value \\
\hline X11 & -0.545 & -0.082 & 0.044 & 0.865 & $<0.001$ \\
\hline X12 & 0.755 & 0.363 & -0.52 & 0.581 & $<0.001$ \\
\hline X13 & 0.751 & 0.053 & 0.105 & 0.194 & $<0.001$ \\
\hline X14 & 0.687 & -0.523 & 0.491 & -0.166 & $<0.001$ \\
\hline X21 & -0.093 & 0.874 & -0.287 & 0.097 & $<0.001$ \\
\hline X22 & -0.306 & 0.843 & -0.163 & 0.07 & $<0.001$ \\
\hline X23 & 0.525 & 0.483 & 0.664 & -0.505 & $<0.001$ \\
\hline X24 & 0.558 & 0.154 & 0.439 & 0.647 & 0.104 \\
\hline X31 & -0.205 & -0.763 & 0.192 & 0.102 & 0.056 \\
\hline
\end{tabular}


Tabel 1 (Lanjutan)

\begin{tabular}{|l|c|c|c|c|c|}
\hline X32 & -0.45 & -0.121 & 0.392 & 0.246 & $<0.001$ \\
\hline X33 & 0.014 & 0.492 & 0.866 & -0.163 & $<0.001$ \\
\hline X34 & -0.122 & 0.279 & 0.838 & 0.014 & $<0.001$ \\
\hline X35 & 0.427 & -0.65 & 0.717 & 0.019 & $<0.001$ \\
\hline Y11 & 0.137 & 0.079 & 0.066 & 0.915 & $<0.001$ \\
\hline Y12 & 0.088 & 0.134 & 0.026 & 0.848 & $<0.001$ \\
\hline Y13 & -0.262 & -0.244 & -0.108 & 0.762 & $<0.001$ \\
\hline
\end{tabular}

Sumber :data primer (diolah WarphPLS Ver 5.0, 2017)

Berdasarkan hasil pengolahan data diatas maka dapat dijelaskan sebagai berikut:

1) Convergent validity untuk konstruk kompleksitas pekerjaaan

Pada model 1 diatas, hasil pengolahan data tersebut menjelaskan bahwa terdapat 1 indikator yang tidak memenuhi standar Convergent validity yaitu $\mathrm{X}_{11}$ $<0,70$, sehingga indikator tersebut harus dikeluarkan dari model, untuk indikator $\mathrm{X}_{14}$ tidak dikeluarkan dari model karena merujuk pada pendapat (Sofyan dan Heri, 2011: 18 dalam Hasanuddin dan Sjahruddin, 2017) nilai standarized loading factor, diatas 0,5 dapat diterima, sedangkan dibawah 0,5 dikeluarkan dari model. Sehingga tidak ada alasan yang kuat untuk mengeluarkan indikator tersebut dan untuk indikator $\mathrm{X}_{12}$ dan $\mathrm{X}_{13}$ memenuhi standar Convergent Validity dengan nilai $>0.70$ dan $\mathrm{P}$-value juga telah memenuhi syarat yaitu memiliki nilai sebesar $<0,001(<0,05)$ dalam semua indikator.

2) Convergent validity untuk konstruk formalisasi pekerjaaan

Hasil pengolahan data pada model 1 diatas menjelaskan bahwa terdapat 2 indikator yang tidak memenuhi standar Convergent validity yaitu, $\mathrm{X}_{23}$ dan $\mathrm{X}_{24}$ $<0.70$, sehingga indikator tersebut harus dikeluarkan dari model, dan untuk indikator $\mathrm{X}_{21}$ dan $\mathrm{X}_{22}$ memenuhi standar Convergent Validity dengan nilai $>0.70$ dan P-value juga telah memenuhi syarat yaitu memiliki nilai sebesar $<0,001<<$ $0,05)$ dalam semua indikator.

3) Convergent validity untuk konstruk sentralisasi pekerjaaan

Hasil pengolahan data pada model 1 diatas menjelaskan bahwa terdapat 2 indikator yang tidak memenuhi standar Convergent validity yaitu, $\mathrm{X}_{31}$ dan $\mathrm{X}_{32}$ $<0.70$, sehingga indikator tersebut harus dikeluarkan dari model, dan untuk indikator $\mathrm{X}_{33,} \mathrm{X}_{34}$ dan $\mathrm{X}_{35}$ memenuhi standar Convergent Validity dengan nilai $>0.70$ dan P-value juga telah memenuhi syarat yaitu memiliki nilai sebesar $<0,001(<0,05)$ dalam semua indikator.

4) Convergent validity untuk konstruk efektifitas kerja

Pada model 1 diatas dapat disimpulkan bahwa dari 3 indikator kinerja pegawai, yaitu $Y_{11}, Y_{12}$, dan $Y_{13}$, semua indikator tersebut memenuhi standar Convergent Validity dengan nilai $>0.70$ dan P-value juga telah memenuhi syarat yaitu memiliki nilai sebesar $<0,001 \quad(<0,05)$ sehingga indikator-indikator tersebut tidak dikeluarkan pada model 2 . 


\section{JURNAL ORGANISASI DAN MANAJEMEN}

Issue 1 (September, 2017)

a) Uji Composite reliability

Penelitian ini menggunakan empat variable laten ( variable yang tidak terukur) yaitu variable kompleksitas pekerjaan $\left(\mathrm{X}_{1}\right)$, formalisasi pekerjaan $\left(\mathrm{X}_{2}\right)$, sentralisasi pekerjaan $\left(\mathrm{X}_{3}\right)$ dan Efektifitas kerja $(\mathrm{Y})$. Suatu variabel yang dipandang mampu (handal) dalam menjelaskan data dari variabel tersebut, pengujiannya dapat dilihat pada nilai composite reliability dan Cronbach's Alpha $<0,60$, Untuk itu dapat diperlihatkan pada tebel berikut:

Tabel 2. Latent Variable Coefficients composite reliability) (model 1)

\begin{tabular}{|l|c|c|c|c|}
\hline MODEL 1 & KP & FP & SP & EK \\
\hline R-Squared & & & & 0.578 \\
\hline Adj. R-squared & & & & 0.556 \\
\hline Composite reliab. & 0.564 & 0.71 & 0.761 & 0.881 \\
\hline Cronbach's Alpha & 0.231 & 0.496 & 0.622 & 0.795 \\
\hline Avg. Var. Extrac. & 0.476 & 0.433 & 0.431 & 0.713 \\
\hline Full Collin. VIF & 1.816 & 2.364 & 1.897 & 2.089 \\
\hline Q-Squared & & & & 0.574 \\
\hline
\end{tabular}

Sumber: Data primer (diolah WarphPLS Ver 5.0, 2017)

Nilai composite reliability untuk variabel kompleksitas pekerjaan sebesar 0,564 $<0,60$ sedangkan untuk variable formalisasi pekerjaan sebesar 0,71 >0,60 dan pada variable sentralisasi pekerjaan sebesar 0,761 > 0,60 dan yang terakhir pada variable efektifitas kerja sebesar 0,881 >0,60. Selanjutnya untuk Cronbach's Alpha pada variabel kompleksitas pekerjaan sebesar $0,231<0,60$, untuk variable formalisasi pekerjaan sebesar $0,496<$ 0,60 sedangkan untuk variable sentralisasi pekerjaan sebesar $0,622>0,60$ dan yang terakhir pada variable efektifitas kerja sebesar 0,795 >0,60. Untuk nilai average variances extracted (AVE) / nilai variasi rata-rata pada variable kompleksitas pekerjaan sebesar 0,476 $<0,50$, untuk variable formalisasi pekerjaan sebesar $0,433<0,50$, sedangkan untuk variable sentralisasi pekerjaan sebesar $0,431<0,50$ dan yang terakhir pada variable efektifitas kerja karyawan sebesar 0,713 >0,50.

Berdasarkan hasil tersebut maka nilai yang belum memenuhi kriteria pengujian di temukan pada nilai variasi rata-rata (AVE) untuk variable kompleksitas pekerjaan, formalisasi pekerjaan dan sentralisasi pekerjaan, sehingga terdapat cukup alasan yang kuat untuk menguji kembali pada model 2.

\section{Evaluasi Model Struktural Pengukuran (Outer Model) Model 2}

Pada model 2 yaitu evaluasi outer model dilakukan melalui 3 kriteria yaitu convergent validity, discriminant validity dan composite reliability. Berikut ini adalah hasil pengolahan data:

\section{a. Convergent Validity (Validitas Konvergen)}

Convergent validity dari model pengukuran dapat dilihat dari korelasi antara skor indikator dengan skor konstruknya (loading factor) dengan kriteria nilai loading factor dari setiap indikator lebih besar dari 0,70 dapat dikatakan valid. Selanjutnya untuk nilai $p$-value apabila < 
Issue 1 (September, 2017)

0,05 dianggap signifikan. Hasil pengolahan Convergent validity dapat dilihat pada table berikut ini:

Tabel 3. Hasil output combined loadings and cross-loading

\begin{tabular}{|c|c|c|c|c|c|}
\hline Model 2 & Komplek & formali & Sentral & E K & P value \\
\hline X12 & 0.793 & 0.305 & -0.404 & 0.466 & $<0.001$ \\
\hline X13 & 0.812 & 0.116 & -0.079 & -0.06 & $<0.001$ \\
\hline X14 & 0.671 & -0.501 & 0.573 & -0.478 & $<0.001$ \\
\hline X21 & 0.150 & 0.899 & -0.077 & -0.04 & $<0.001$ \\
\hline X22 & -0.150 & 0.899 & 0.077 & 0.04 & $<0.001$ \\
\hline X33 & -0.024 & 0.28 & 0.892 & -0.036 & $<0.001$ \\
\hline X34 & -0.203 & 0.304 & 0.851 & 0.003 & $<0.001$ \\
\hline X35 & 0.264 & -0.692 & 0.735 & 0.039 & $<0.001$ \\
\hline Y21 & 0.216 & 0.109 & 0.04 & 0.915 & $<0.001$ \\
\hline Y22 & 0.163 & 0.147 & 0.054 & 0.848 & $<0.001$ \\
\hline Y23 & -0.441 & -0.294 & -0.107 & 0.762 & $<0.001$ \\
\hline
\end{tabular}

Sumber : Kuesioner penelitian (data diolah, 2017)

Hasil pada tabel diatas, menunjukkan hasil pengujian Convergent validity untuk model 2, dimana pada model 1 sebelumnya terdapat beberapa indikator pada variabel kompleksitas pekerjaan, formalisasi pekerjaan, sentralisasi pekerjaan dan efektifitas kerja yang tidak memenuhi standar Convergent validity sehingga dilakukan pengujian model 2. Pada pengujian model 2 diatas, semua indikator yang tidak memenuhi standar Convergent validity telah dikeluarkan dari model, sehingga pengujian Convergent validity pada model 2 telah memenuhi standar Convergent Validity dengan nilai $>0.70$ dan P-value juga telah memenuhi syarat yaitu memiliki nilai sebesar $<0,001(<0,05)$ untuk seluruh indikator dari variabel kompleksitas pekerjaan, formalisasi pekerjaan, senatralisasi pekerjaan, dan efektifitas kerja.

b) Uji Composite reliability

Suatu variabel yang dipandang mampu (handal) dalam menjelaskan data dari variabel tersebut, pengujiannya dapat dilihat pada nilai composite reliability dan Cronbach's Alpha $<0,60$, untuk itu dapat diperlihatkan pada tabel berikut:

Tabel 4. latent variable coefficients (composite reliability) (model 2)

\begin{tabular}{|l|l|l|l|l|}
\hline \multicolumn{1}{|c|}{ MODEL 2 } & KP & FP & SP & EK \\
\hline R-Squared & & & & 0.626 \\
\hline Adj. R-squared & & & & 0.607 \\
\hline Composite reliab. & 0.804 & 0.894 & 0.868 & 0.881 \\
\hline Cronbach's Alpha & 0.633 & 0.763 & 0.769 & 0.795 \\
\hline Avg. Var. Extrac. & 0.579 & 0.808 & 0.687 & 0.713 \\
\hline Full Collin. VIF & 2.166 & 1.786 & 1.763 & 2.422 \\
\hline Q-Squared & & \multicolumn{3}{|l}{} \\
\hline
\end{tabular}

Sumber: Data primer (diolah WarphPLS Ver 5.0, 2017)

Nilai composite reliability untuk variabel kompleksitas pekerjaan sebesar $0,804>0,60$ untuk variable formalisasi pekerjaan sebesar 0,894 > 0,60 sedangkan

Author : Taufiq Wahyudi dkk. (September, 2017). 29 - 46

Halaman 38 
untuk variable sentralisasi pekerjaan sebesar $0,868>0,60$ dan yang terakhir variable efektifitas kerja sebesar 0,881 > 0,60. Selanjutnya untuk Cronbach's Alpha pada variabel kompleksitas pekerjaan sebesar $0,633>0,50$ untuk variable formalisasi pekerjaan sebesar 0,763>0,50 sedangkan untuk variable sentralisasi pekerjaan sebesar $0,769>0,50$ dan yang terakhir variable efektifitas kerja sebesar $0,795>0,50$. Berdasarkan hasil tersebut maka keseluruhan nilai memenuhi kriteria pengujian, sehingga terdapat alasaan yang kuat untuk dianalisis lebih lanjut.

Tabel 5. Nilai (Average Variance Extracted) (model 2)

\begin{tabular}{|l|c|c|c|}
\hline Variabel Laten & Nilai AVE & Kriteria & Keterangan \\
\hline KP & 0,579 & $>0,50$ & Terpenuhi \\
\hline FP & 0,808 & $>0,50$ & Terpenuhi \\
\hline SP & 0,687 & $>0,50$ & Terpenuhi \\
\hline EK & 0,713 & $>0,50$ & Terpenuhi \\
\hline
\end{tabular}

Sumber: Data primer (diolah WarphPLS Ver 5.0, 2017)

Berdasarkan hasil tersebut keempat konstruk telah memenuhi convergent validity. Kompleksitas pekerjaan dengan nilai 0,579 $>0,50$, formalisasi pekerjaan dengan nilai $0,808>0,50$, sentralisasi pekerjaan dengan nilai 0,687 juga telah memenuhi nilai $>0,50$. Kesimpulannya keseluruhan variable telah memenuhi kriteria convergent validity.

c) Discriminant Validity

Discriminant validity dinilai dari cross loading pengukuran dengan konstruk. Dapat dilihat dengan melihat loading konstruk laten, yang akan memprediksi indikatornya lebih baik daripada konstruk lainnya. Jika korelasi konstruk dengan pokok pengukuran (setiap indikator) lebih besar daripada ukuran konstruk lainnya maka validitas diskriminan terpenuhi.

Tabel 6. Nilai loading konstruk laten indicator ke konstruk lainnya

\begin{tabular}{|c|c|c|c|c|c|c|c|}
\hline \multirow[t]{2}{*}{ Indikator } & \multirow[t]{2}{*}{ Loading } & & \multicolumn{4}{|c|}{ Nilai Loading ke konstruk lainnya } & \multirow[t]{2}{*}{ Keterangan } \\
\hline & & & KP & FP & SP & EK & \\
\hline X12 & 0.793 & $>$ & & 0.305 & -0.404 & 0.466 & $\begin{array}{l}\text { Memenuhi } \\
\text { Discriminant validity }\end{array}$ \\
\hline $\mathrm{X} 13$ & 0.812 & $>$ & & 0.116 & -0.079 & -0.06 & $\begin{array}{l}\text { Memenuhi } \\
\text { Discriminant validity }\end{array}$ \\
\hline X14 & 0.671 & $>$ & & -0.501 & 0.573 & -0.478 & \begin{tabular}{|l} 
Memenuhi \\
Discriminant validity
\end{tabular} \\
\hline$\times 21$ & 0.899 & $>$ & 0.15 & & -0.077 & -0.04 & $\begin{array}{l}\text { Memenuhi } \\
\text { Discriminant validity }\end{array}$ \\
\hline $\mathrm{X} 22$ & 0.899 & $>$ & -0.15 & & 0.077 & 0.04 & $\begin{array}{l}\text { Memenuhi } \\
\text { Discriminant validity }\end{array}$ \\
\hline X33 & 0.892 & $>$ & -0.024 & 0.28 & & -0.036 & $\begin{array}{l}\text { Memenuhi } \\
\text { Discriminant validity }\end{array}$ \\
\hline X34 & 0.851 & $>$ & -0.203 & 0.304 & & 0.003 & $\begin{array}{l}\text { Memenuhi } \\
\text { Discriminant validity }\end{array}$ \\
\hline X35 & 0.735 & $>$ & 0.264 & -0.692 & & 0.039 & $\begin{array}{l}\text { Memenuhi } \\
\text { Discriminant validity }\end{array}$ \\
\hline Y11 & 0.915 & $>$ & 0.216 & 0.109 & 0.04 & & $\begin{array}{l}\text { Memenuhi } \\
\text { Discriminant validity }\end{array}$ \\
\hline Y12 & 0.848 & $>$ & 0.163 & 0.147 & 0.054 & & $\begin{array}{l}\text { Memenuhi } \\
\text { Discriminant validity }\end{array}$ \\
\hline Y13 & 0.762 & $>$ & -0.441 & -0.294 & -0.107 & & $\begin{array}{l}\text { Memenuhi } \\
\text { Discriminant validity }\end{array}$ \\
\hline
\end{tabular}

Sumber: Data primer (diolah WarphPLS Ver 5.0, 2017)

Author : Taufiq Wahyudi dkk. (September, 2017). 29 - 46 


\section{JURNAL ORGANISASI DAN MANAJEMEN}

Issue 1 (September, 2017)

Berdasarkan data diatas, keseluruhan indikator telah memenuhi kriteria validitas diskriminan. Variable kompleksitas pekerjaan yang memiliki 3 indikator yang dilambangkan $\mathrm{X}_{12}, \mathrm{X}_{13}$, dan, $\mathrm{X}_{14}$. untuk indikator $\mathrm{X}_{12}$ memiliki nilai loading 0,793 yang nilai loading-nya lebih besar dari loading ke konstruk lain yaitu 0,305, 0,404 dan -0,466 dan ke 3 indikator kompleksitas karyawan lainnya juga memiliki nilai loading yang lebih besar dari nilai loading ke konstruk lainnya.

Variable formalisasi pekerjaan yang memiliki 2 indikator yang dilambangkan $\mathrm{X}_{21}$ dan $\mathrm{X}_{22}$. untuk indikator $\mathrm{X}_{21}$ memiliki nilai loading 0,899 yang nilai loading nya lebih besar dari loading ke konstruk lain yaitu $0,15,-0,077$,dan -0,04 dan indikator lainnya juga memiliki nilai loading yang lebih besar dari nilai loading ke konstruk lainnya.

Variable sentralisasi pekerjaan yang memiliki 3 indikator yang dilambangkan $\mathrm{X}_{33}, \mathrm{X}_{34}$, dan $\mathrm{X}_{35}$. Untuk indikator $\mathrm{X}_{33}$ memiliki nilai loading 0,892 yang nilai loadingnya lebih besar dari loading ke konstruk lain yaitu -0,024, 0,28, dan 0,036 dan indikator lainnya juga memiliki nilai loading yang lebih besar dari nilai loading ke konstruk lainnya.

Variable efektifitas kerja memiliki 3 indikator yang dilambangkan $Y_{11}, Y_{12}$, dan $Y_{13}$. Untuk indikator $Y_{11}$ memiliki nilai loading 0,915 yang nilai loading - nya lebih besar dari loading konstruk lain yaitu 0,216, 0,109, dan 0,04 dan indikator lainnya juga memiliki nilai loading yang lebih besar dari nilai loading ke konstruk lainnya.

\section{Evaluasi Model Struktural (Inner Model)}

Tahap selanjutnya adalah melakukan evaluasi struktural (inner model) yang meliputi uji kecocokan model (model fit), path coefficient, dan $\mathrm{R}^{2}$. Pada uji kecocokan model terdapat 3 indeks pengujian, yaitu average path coefficient (APC), average $R$-squared (ARS) dan average varians factor (AVIF) dengan kriteria APC dan ARS diterima dengan syarat $p-$ value $<0,05$ dan AVIF lebih kecil dari 5 (Mahfud Sholihin dan Dwi Ratmono, 2013: 61).

Tabel 7. Hasil output model fit indices

\begin{tabular}{|l|l|l|c|l|}
\hline & Indeks & P-Value & Kriteria & Keterangan \\
\hline APC & 0,307 & $\mathrm{P}=0,002$ & $\mathrm{P}<0,05$ & Diterima \\
\hline ARS & 0,626 & $\mathrm{P}<0,001$ & $\mathrm{P}<0,05$ & Diterima \\
\hline AVIF & 1,737 Acceptable if $<5$ & & $\mathrm{AVIF}<5$ & Diterima \\
\hline
\end{tabular}

Sumber: Data primer (diolah WarphPLS Ver 5.0, 2017)

Hasil output diatas, menjelaskan bahwa APC memiliki indeks sebesar 0,307 dengan nilai $p-$ value $<0,002$. Sedangkan ARS memiliki indeks sebesar 0,626 dengan $p$-value $<0,001$. Berdasarkan kriteria, APC sudah memenuhi kriteria karena memiliki nilai $\mathrm{P}=0,002$, begitu pula dengan nilai $\mathrm{p}$ dari ARS yaitu $\mathrm{p}<0,001$. Nilai AVIF yang harus $<5$ sudah terpenuhi karena berdasarkan data . tersebut AVIF nilainya 1,737. Dengan demikian, maka inner model dapat diterima.

a. Hasil Uji Hipotesis

1) Hasil korelasi antar konstruk diukur dengan melihat path coefficients dan tingkat signifikansinya yang kemudian dibandingkan dengan hipotesis penelitian yang terdapat di bab dua. Tingkat signifikansi yang dipakai dalam penelitian ini adalah sebesar 5\%. Berikut ini hipotesis yang dimaksudkan untuk membuktikan kebenaran dugaan penelitian yang terdiri dari tiga hipotesis, yaitu:

$\mathrm{H}_{1}=$ Kompleksitas pekerjaan berpengaruh positif dan signifikan terhadap efektifitas kerja karyawan

Halaman 40

Author : Taufiq Wahyudi dkk. (September, 2017). 29 - 46 


\section{JURNAL ORGANISASI DAN MANAJEMEN}

Issue 1 (September, 2017)

$\mathrm{H}_{2}=$ Formalisasi pekerjaan berpengaruh positif dan signifikan terhadap efektifitas kerja karyawan

$\mathrm{H}_{3}=$ Sentralisasi pekerjaan berpengaruh positif dan signifikan terhadap efektifitas kerja karyawan

$\mathrm{H}_{4}=$ Kompleksitas pekerjaan merupakan variable dominan berpengaruh terhadap efektifitas kerja karyawan

Berikut ini gambar hasil penelitian dari yang telah diperoleh berdasarkan pengolahan data:

Gambar 1. Full Model

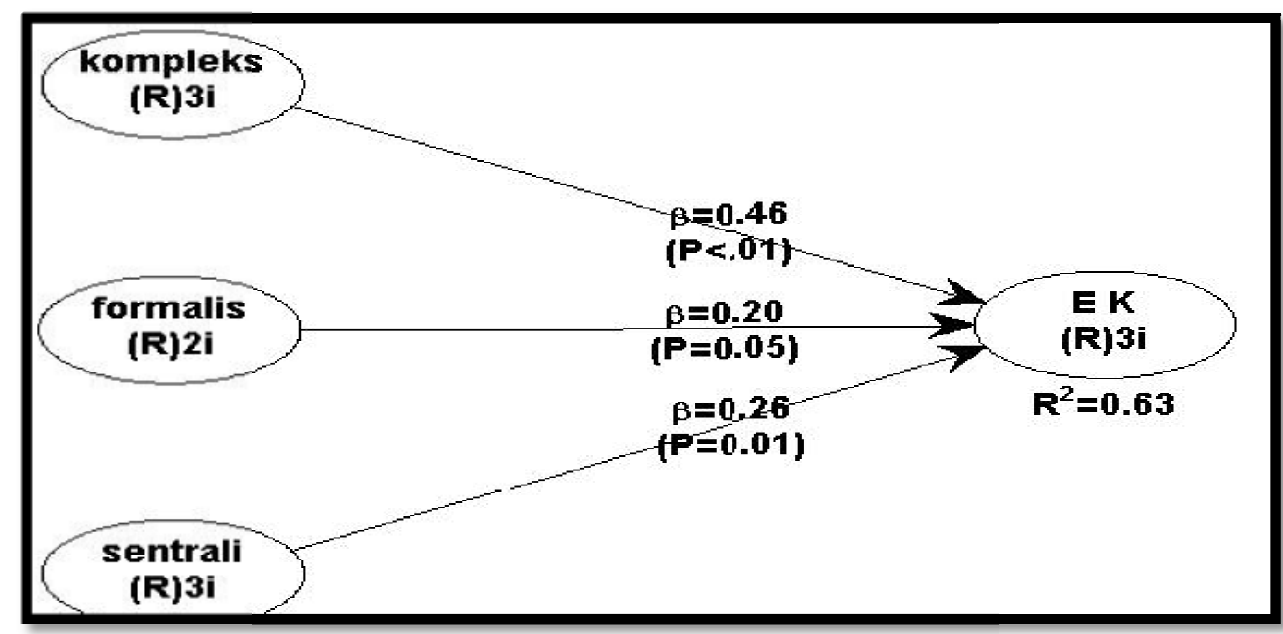

Sumber: Data Primer (diolah WarphPLS Ver 5.0 2017)

$\begin{array}{cll}\text { Keterangan : } & \text { Kompleks } & \text { : Kompleksitas pekerjaan } \\ & \text { Formalis } & \text { : Formalisasi pekerjaan } \\ \text { Sentrali } & \text { : Sentralisasi pekerjaan } \\ \text { E K } & \text { : Efektifitas kerja }\end{array}$

Tabel 8. Pengujian hipotesis

\begin{tabular}{|c|c|c|c|c|c|}
\hline Kriteria & Variabel & KP & FP & SP & EK \\
\hline \multirow[t]{4}{*}{ Path coefficients } & KP & & & & \\
\hline & FP & & & & \\
\hline & SP & & & & \\
\hline & EK & 0.459 & 0.203 & 0.26 & \\
\hline \multirow[t]{4}{*}{$p$-values } & KP & & & & \\
\hline & FP & & & & \\
\hline & SP & & & & \\
\hline & EK & $<0.001$ & 0.046 & 0.014 & \\
\hline \multirow{4}{*}{$\begin{array}{l}\text { Effect size for } \\
\text { path }\end{array}$} & $\mathbf{K P}$ & & & & \\
\hline & FP & & & & \\
\hline & SP & & & & \\
\hline & EK & 0.338 & 0.125 & 0.164 & \\
\hline
\end{tabular}

Halaman 41

Author : Taufiq Wahyudi dkk. (September, 2017). 29 - 46 


\section{JURNAL ORGANISASI DAN MANAJEMEN}

Issue 1 (September, 2017)

Sumber: Data primer (diolah WarphPLS Ver 5.0, 2017)

Hasil output diatas, menjelaskan bahwa path coefficients untuk variable kompleksitas pekerjaan terhadap efektifias kerja karyawan memiliki indeks sebesar 0,459 dengan nilai $p$-value $<0,001$ dan nilai effect size for path 0,338, untuk path coefficients variable formalisasi pekerjaan terhadap efektifitas kerja memiliki indeks sebesar 0,203 dengan $p$-value 0,046 nilai effect size for path 0,125, sedangkan untuk path coefficients sentralisasi pekerjaan terhadap efektifitas kerja memiliki indeks sebesar 0,26 dengan $p$-value 0,014 nilai effect size for path 0,164.

Setelah melakukan uji hipotesis, berikut ini table yang merangkum uji hipotesis tersebut :

Tabel 9. Hasil Uji Hipotesis

\begin{tabular}{|l|l|l|l|l|}
\hline Hipotesis & Independen & Dependen & p-values & Keputusan \\
\hline $\mathrm{H}_{1}$ & Efektifitas kerja & $\begin{array}{l}\text { Kompleksitas } \\
\text { pekerjaan }\end{array}$ & $<0,001$ & Diterima \\
\hline $\mathrm{H}_{2}$ & Efektifitas kerja & Formalisasi pekerjaan & $<0,0463$ & Diterima \\
\hline $\mathrm{H}_{3}$ & Efektifitas kerja & Sentralisasi pekerjaan & $<0,014$ & Diterima \\
\hline $\mathrm{H}_{4}$ & Efektifitas kerja & $\begin{array}{l}\text { Kompleksitas } \\
\text { pekerjaan, formalisasi } \\
\text { pekerjaan, sentralisasi } \\
\text { pekerjaan }\end{array}$ & $\begin{array}{l}\text { Nilai } 0,460 \\
>0,203 \text { dan } \\
0,260\end{array}$ & Diterima \\
\hline
\end{tabular}

Sumber: Data primer (diolah WarphPLS Ver 5.0, 2017)

Berdasarkan tabel hasil uji hipotesis di atas, dapat diperoleh:

1. Uji hipotesis 1 diterima, artinya variable kompleksitas pekerjaan memiliki pengaruh positif dan signifikan terhadap efektifitas kerja karyawan pada PT. Inti Karsa Persada Makassar. Hal ini ditunjukkan dengan nilai beta $(\beta)$ sebesar 0,46 dengan nilai $p$-value $<0.001$.

2. Uji hipotesis 2 diterima, artinya variable formalisasi pekerjaan memiliki pengaruh positif dan signifikan terhadap efektifitas kerja karyawan pada PT. Inti Karsa Persada Makassar. Hal ini ditunjukkan nilai beta $(\beta)$ sebesar 0,203 dengan nilai $p$-value $<0.0463$.

3. Uji hipotesis 3 diterima, artinya variable sentralisasi pekerjaan memiliki pengaruh positif dan signifikan terhadap efektifitas kerja karyawan karyawan pada PT. Inti Karsa Persada Makassar. Hal ini ditunjukkan nilai beta $(\beta)$ sebesar 0,26 dengan nilai $p$-value $<0,014$.

4. Uji hipotesis 4 diterima, artinya variable kompleksitas pekerjaan dominan memiliki pengaruh positif dan signifikan terhadap efektifitas kerja karyawan karyawan pada PT. Inti Karsa Persada Makassar. Hal ini ditunjukkan dengan variabel kompleksitas karyawan memiliki nilai lebih tinggi yaitu nilai beta $(\beta)$ sebesar sebesar 0,46 dengan nilai $p$-value $<0.001$ dibandingkan dengan variable formalisasi pekerjaan dengan nilai beta $(\beta)$ sebesar 0,203 dengan nilai $p$-value $<0.0463$ dan variable sentralisasi pekerjaan dengan nilai beta $(\beta)$ sebesar 0,26 dengan nilai $p$-value $<0,014$.

\section{b. Pengaruh variabel independen terhadap variabel dependen}

Pengujian besaran pengaruh variabel independen terhadap variabel dependen dapat ditunjukkan pada tabel berikut 
Tabel 10. Ringkasan Model (model summary)

\begin{tabular}{|l|l|l|l|l|}
\hline Pengukuran & KP & FP & SP & EK \\
\hline R-squared & & & & 0.626 \\
\hline Adj. -squared & & & & 0.607 \\
\hline Composite reliab. & 0.804 & 0.894 & 0.868 & 0.881 \\
\hline Cronbach's Alpha & 0.633 & 0.763 & 0.769 & 0.795 \\
\hline Avg. Var. Extrac. & 0.579 & 0.808 & 0.687 & 0.713 \\
\hline
\end{tabular}

Sumber: Data primer (diolah WarphPLS Ver 5.0, 2017)

Berdasarkan table diatas besaran pengaruh nilai $R$-squared pada variabel kompleksitas pekerjaan, formalisasi pekerjaan, dan sentralisasi pekerjaan terhadap efektifitas kerja karyawan adalah 0,626 (62,6\%) dan sisanya $37,4 \%$ dipengaruhi oleh variable lain yang tidak dianalisis dalam penelitian ini seperti lingkungan kerja, kompensasi dan variable lainnya.

\section{1) Pengaruh kompleksitas pekerjaan terhadap efektifitas kerja karyawan}

Berdasarkan hasil penelitian, ditemukan bahwa kompleksitas pekerjaan memiliki pengaruh terhadap efektifitas kerja karyawan. Hasil ini sama dengan teori atau temuan dalam penelitian sebelumnya oleh Gammahendra dkk (2014) memberikan bukti bahwa kompleksitas pekerjaan berpengaruh positif dan signifikan terhadap efektifitas kerja. Dalam penelitian ini dapat dilihat dari nilai koefisien beta yang menunjukkan bahwa semakin baik kompleksitas pekerjaan maka semakin tinggi efektifitas kerja karyawan yaitu dengan nilai beta $(\beta)$ sebesar 0,46 . Nilai $\mathrm{R}^{2}$ dapat dilihat pada effect size, nilainya sebesar 0,338 yang berarti bahwa kompleksitas pekerjaan mempengaruhi variable efektifitas kerja karyawan pada PT. Inti Karsa Persada Makassar sebesar 33,8\%.

Hal ini menunjukkan bahwa variable kompleksitas pekerjaan dapat mempengaruhi peningkatan efektifitas kerja yang cukup besar. Sehingga dapat disimpulakan, semakin baik kompleksitas pekerjaan maka efektifitas kerja karyawan semakin meningkat. Artinya perusahaan yang menerapkan kompleksitas pekerjaan dengan baik dan dapat membentuk kemampuan karyawan dengan baik dapat mempengaruhi efektifitas kerja tersebut. Efektifitas kerja berdampak baik pada tujuan yang ingin dicapai perusahaan sehingga dapat menyejahterakan perusahaan dan pihak berkepentingan lainnya sehingga perlunya peningkatan kompleksitas pekerjaan yang tinggi.

\section{2) Pengaruh formalisasi pekerjaan terhadap efektifitas kerja karyawan}

Berdasarkan hasil penelitian, ditemukan bahwa formalisasi pekerjaan memiliki pengaruh terhadap efektifitas kerja. Hasil ini sama dengan teori atau temuan sebelumnya oleh Gina mardiana, (2011) bahwa struktur organisasi melalui dimensi formalisasi pekerjaan secara parsial berpengaruh terhadap efektifitas kerja yg dicerminkan melalui sistem informasi akuntansi. Dalam penelitian ini dapat dilihat dari nilai koefisien beta yang menunjukkan bahwa formalisasi pekerjaan memiliki pengaruh positif dan signifikan terhadap efektifitas kerja yaitu dengan 


\section{JURNAL ORGANISASI DAN MANAJEMEN}

Issue 1 (September, 2017)

nilai beta $(\beta)$ sebesar 0,203 . Nilai $\mathrm{R}^{2}$ dapat dilihat pada effect size, nilainya sebesar 0,125 yang berarti bahwa variabel kompleksitas pekerjaan memengaruhi efektifitas kerja karyawan pada PT. Inti Karsa Persada Makassar sebesar 12,5\%.

Hal ini menunjukkan bahwa variable formalisasi pekerjaan dapat mempengaruhi efektifitas kerja cukup rendah. Sehingga dapat disimpulakan, semakin rendah formalisasi pekerjaan maka efektifitas kerja karyawan semakin rendah pula begitu juga sebaliknya jika formalisasi pekerjaan tinggi maka efektifitas kerja juga akan meningkat. Artinya perusahaan perlu menerapkan formalisasi pekerjaan dengan lebih baik sehingga mampu membentuk kemampuan karyawan dalam meningkatkan efektifitas kerjanya. Efektifitas kerja berdampak baik pada pencapaian tujuan perusahaan sehingga dapat menyejahterakan perusahaan dan pihak berkepentingan lainnya sehingga perlu adanya peningkatan formalisasi pekerjaan.

\section{3) Pengaruh sentralisasi pekerjaan terhadap efektifitas kerja karyawan}

Berdasarkan hasil penelitian ditemukan bahwa sentralisasi pekerjaan memiliki pengaruh terhadap efektifitas kerja .Hasil ini sama dengan teori atau temuan dalam penelitian sebelumnya oleh Gammahendra dkk (2014) memberikan bukti bahwa sentralisasi pekerjaan berpengaruh positif dan signifikan terhadap efektifitas kerja karyawan. Dalam penelitian ini dapat dilihat dari nilai koefisien beta yang menujukkan bahwa semakin baik sentralisasi pekerjaan maka semakin tinggi efektifitas kerja karyawan yaitu dengan nilai beta $(\beta)$ sebesar 0,26 . Nilai $R^{2}$ dapat dilihat pada effect size, nilainya sebesar 0,164 yang berarti bahwa variabel sentralisasi pekerjaan memengaruhi efektifitas kerja karyawan di PT. Inti Karsa Persada Makassar sebesar 16,4\%.

Hal ini menunjukkan bahwa variable sentralisasi pekerjaan dapat mempengaruhi peningkatan efektifitas kerja yang cukup besar. Sehingga dapat disimpulakan, semakin baik sentralisasi pekerjaan maka efektifitas kerja karyawan semakin meningkat. Artinya perusahaan yang menerapkan kompleksitas pekerjaan dengan baik dan dapat membentuk kemampuan karyawan dengan baik dapat mempengaruhi efektifitas kerja tersebut. Efektifitas kerja berdampak baik pada tujuan yang ingin dicapai perusahaan sehingga dapat menyejahterakan perusahaan dan pihak berkepentingan lainnya sehingga perlunya peningkatan sentralisasi pekerjaan yang tinggi.

\section{4) Pengaruh kompleksitas pekerjaan dominan dibandingkan formalisasi dan sentralisasi pekerjaan terhadap efektifitas kerja karyawan}

Berdasarkan hasil penelitian, ditemukan bahwa pengaruh kompleksitas pekerjaan lebih dominan dibandingakan pengaruh formalisasi dan sentralisasi pekerjaan terhadap efektifitas kerja karyawan.Hasil tersebut dalam penelitian ini dapat dilihat dari nilai koefiisen beta yang ditunjukkan kompleksitas pekerjaan lebih tinggi yaitu dengan nilai beta $(\beta)$ sebesar 0,46 . Dan nilai koefisien beta yang ditunjukkan oleh formalisasi pekerjaan yaitu dengan nilai 0,203 sedangkan yang ditunjukkan oleh sentralisasi pekerjaan yaitu dengan nilai 0,26 . Nilai $\mathrm{R}^{2}$ dapat dilihat pada effect size, nilai untuk kompleksitas pekerjaan sebesar 0,338 $(33,8 \%)$ dan nilai untuk formalisasi pekerjaan sebesar 0,125 (12,5\%) sedangkan untuk sentralisasi pekerjaan sebesar 0,164 (16,4\%) yang mempengaruhi variabel efektifitas kerja karyawan pada PT. Inti Karsa Persada Makassar. 


\section{JURNAL ORGANISASI DAN MANAJEMEN}

Issue 1 (September, 2017)

Hal ini menunjukkan bahwa variabel komplesitas pekerjaan lebih tinggi memengaruhi peningkatan efektifitas kerja karyawan dibandingkan variable formalisasi dan kompleksitas pekerjaan. Sehigga dapat disimpulakan, kompleksitas pekerjaan lebih dominan mempengaruhi efektifitas kerja jika dibandingkan dengan variabel formalisasi dan sentralisasi pekerjaan. Artinya perusahaan harus lebih menyimbangkan pengaruh ketiga variable tersebut agar dapat meningkatkan pencapaian efektifitas kerja karyawan yang tinggi.

\section{Kesimpulan dan Saran}

Kebebasan dalam bekerja memiliki pengaruh positif dan signifikan terhadap intensi berwirausaha. Keberhasilan diri yang lebih besar yang diperoleh mahasiswa dapat meningkatkan jiwa entrepreneur (wirausahawan) dalam diri mahasiswa. Toleransi resiko memiliki pengaruh positif dan signifikan terhadap intensi berwirausaha. Toleransi yang lebih besar terhadap risiko akan memberikan jiwa entrepreneur (wirausahawan) yang lebih besar dalam diri mahasiswa. Keberhasilan diri memiliki pengaruh positif dan signifikan terhadap intensi berwirausaha. Kebebasan yang lebih besar dalam pemilihan pekerjaan akan memberikan jiwa entrepreneur (wirausahawan) yang lebih besar dalam diri mahasiswa. Kebebasan dalam bekerja memiliki pengaruh positif dan signifikan yang dominan terhadap keinginan mahasiswa untuk menjadi seorang entrepreneur (wirausahawan).

Berkaitan dengan faktor Keberhasilan diri, aspek ketekunan dan keuletan dalam bekerja nampaknya masih menjadi hal yang paling kurang diperhatikan oleh mahasiswa. Untuk itu dalam banyak hal mengaitkan ketekunan dalam kuliah dan keuletan sebagai bagian awal dari pemupukan jiwa kewirausahaan nampaknya harus menjadi latihan awal mahasiswa. Faktor toleransi resiko, kesukaan akan tantangan yang dimiliki mahasiswa dapat memperkecil toleransi resiko yang dipupuk. Untuk itu berbagai pembelajaran diri dalam menemukan tantangan baru harus selalu dimiliki mahasiswa. Faktor kebebasan dalam bekerja, aspek pengambilan prakarasa atau inisiatif harus menjadi salah satu upaya untuk memperoleh peluang dan membuat peluang usaha baru. Dengan demikian hal ini mesti dilatih dalam pembelajaran di kampus.

\section{DAFTAR PUSATAKA}

Adhitama, Paulus Patria. 2014. Faktor-Faktor Yang Mempengaruhi Minat Berwirausaha (Studi Kasus Mahasiswa Fakultas Ekonomika dan Bisnis Undip, Semarang). Skripsi: tidak diterbitkan. 1-52.

Ahda Vilathuvahna, Ananda dan R D A Nugroho, Taufik. 2015. Intensi Kewirausahaan Mahasiswa Universitas Trunojoyo Madura. Agriekonomika, Vol 4, No. 1. 107-119.

Angki Adi Tama. 2010. Analisis Faktor-Faktor yang Memotivasi Mahasiswa Berkeinginan Menjadi Entepreneur (Studi pada Mahasiswa S1 Fakultas Ekonomi Universitas Dipenegoro Semarang). Skripsi: diakses dari www.eprints.undip.ac.id.

Ariyani, Lilis. 2016. Faktor-Faktor Yang Mempengaruhi Intensi Berwirausaha Pada Kalangan Mahasiswa (Studi Kasus Pada Mahasiswa FEB UMS). Skripsi: tidak diterbitkan. 1-19.

Azwar, Saifuddin. 2012. Sikap Manusia. Teori dan Pengukurannya. Cetakan XVII. Pustaka Pelajar Offset. Yogyakarta.

Author : Taufiq Wahyudi dkk. (September, 2017). 29 - 46 


\section{JURNAL ORGANISASI DAN MANAJEMEN}

Issue 1 (September, 2017)

Handaru, Agung Wahyu, dkk. 2014. Pengaruh Sikap, Norma Subjektif, dan Efikasi Diri Terhadap Intensi Berwirausaha Mahasiswa Magister Management (Kajian Empiris pada Sebuah Universitas Negeri di Jakarta). 1046-1061.

Maharini. 2013. Analisis Diskriminan Kepuasan Masyarakat Terhadap Kualitas Pelayanan Administratif Di Kantor Kecamatan Tulakan Kabupaten Pacitan. Skripsi: tidak diterbitkan.1-113.

Mahesa, Aditya Dion. 2012. Analisis Faktor-Faktor Motivasi yang Mempengaruhi Minat Berwirausaha. Diponegoro Journal of Management. 130-137.

Malo, Matesh dan Amelia. 2011. Analisis Faktor-Faktor yang Mempengaruhi Niat Kewirausahaan Mahasiswa Universitas Pelita. Jurnal Ekonomi Universitas Pelita Harapan Surabaya, 2(12), 79-84.

Pangkey, Max. 2010. Analisis Faktor-Faktor Penyebab Pengunduran Diri Karyawan Waktu Tertentu Pada Pt. Sinar Pure Foods International. Journal Article. h: 11.

Pratiwi, Yenni dan Wardana, I. 2016. Pengaruh Faktor Internal dan Eksternal Terhadap Minat Berwirausaha Mahasiswa Fakultas Ekonomi dan Bisnis Universitas Udayana. E-Jurnal Manajemen Unud, Vol.5. h. 1-28.

Raditya, K. (2016). Pengaruh Lingkungan Kerja Fisik Dan Kompensasi Finansial Terhadap Kepuasan Kerja Bagian Tukang Jahit Yara Garment. E-Jurnal Manajemen Universitas Udayana, 5(3).

Rahmadi, Afif Nur dan Heryanto Budi. 2010. Analisis Faktor-Faktor Yang Mempengaruhi Minat Berwirausaha Pada Mahasiswa Program Studi Manajemen Fakultas Ekonomi Universitas Kadiri. Skripsi: tidak diterbitkan. h: 1-17.

Santosa, Tri Djoko, Pengaruh Adversity Quotient Dan Faktor Kontekstual Terhadap Intensi Berwirausaha Berbasis Teknologi (Technopreneurship) Mahasiswa Stmik Duta Bangsa. Duta.com, Vol. 8, No.2. h: 1-7.

Sjahruddin, Herman. 1980. Discrimnant Analysis (Analisis Diskriminan) Disajikan Pada Kuliah Metode Kuantitatif Manajemen. Bahan Kuliah Program Magister STIM Nitro. 1-71.

Suhartini, Yati. 2011. Analisis Faktor-Faktor yang Mempengaruhi Minat Mahasiswa Dalam Berwirausaha (Studi Pada Mahasiswa Universitas PGRI Yogyakarta). AKMENIKA UPY. 9(10): 1-15.

Sulistiyorini, Ika. 2013. Analisis Faktor-Faktor Yang Mempengaruhi Kepuasan

Pelanggan Internet Speedy Reguler Menggunakan Analisis Diskriminan Di

Semarang. Skripsi: tidak diterbitkan. hal: 1-122.

Sumarsono, Hadi. 2012. Faktor-Faktor yang Mempengaruhi Intensi Wirausaha Mahasiswa Universitas Muhammadiyah Ponogoro. Jurnal M anajemen, 11(2): 1-22.

Susanto, Adi. 2000. Kewirausahaan : Ghalia Indonesia. Jakarta.

Uswaturrasul, Yahya dan Sisilia, Kristina. 2011. Analisis Minat dan Motivasi Berwirausaha Mahasiswa (Pada Program Studi Administrasi Bisnis Telkom University, Angkatan 2011) Skripsi: tidak diterbitkan. 2(2) h: 1-11.

Wahab, Zulkifli S. 2015. Pengaruh Motivasi dan Mental Kewirausahaan Terhadap Minat Mahasiswa Manajemen Untuk Berwirausaha (Studi Pada Mahasiswa Prodi Manajemen Stiem Bongaya Makassar). Skripsi: tidak diterbitkan. 1-63. 